\title{
Negotiating agency: Amish and ultra-Orthodox women's responses to the Internet
}

new media \& society 2017, Vol. 19(I) 8I-95

(C) The Author(s) 2016

Reprints and permissions: sagepub.co.uk/journalsPermissions.nav DOI: |0.1 |77/|46|4448|6649920 journals.sagepub.com/home/nms

@SAGE

\section{Rivka Neriya-Ben Shahar}

Sapir Academic College, Israel

\begin{abstract}
This study explores how women in two devout religious communities cope with the Internet and its apparent incompatibility with their communities' values and practices. Questionnaires containing both closed and open-ended questions were completed by 82 participants, approximately half from each community. While their discourses included similar framings of danger and threat, the two groups manifested different patterns of Internet use (and nonuse). Rigorous adherence to religious dictates is greatly admired in these communities, and the women take pride in manipulating their status in them. Their agency is reflected in how they negotiate the tension inherent in their roles as both gatekeepers and agents-of-change, which are analyzed as valuable currencies in their cultural and religious markets.
\end{abstract}

\section{Keywords}

Agency, agents-of-change, Amish, gatekeepers, Internet, nonuse, religious communities, ultra-Orthodox, women

\section{Introduction}

While contemporary research regarding Internet use and religion mostly explores how the Internet functions as a tool for religious communities, their practices, and experiences (Campbell, 2013, 2015), this article focuses on how the non (or limited) use of the Internet creates valuable cultural and religious capital for women from two devout religious communities-Amish and ultra-Orthodox Jewish (Haredi). ${ }^{1}$ It explores these

\section{Corresponding author:}

Rivka Neriya-Ben Shahar, Sapir Academic College, D.N. Hof Ashkelon 79I65, Israel.

Email: rivka.nbs@gmail.com 
women's media use and perceptions regarding the Internet, tracing how they negotiate the incongruence between the Internet's advantages and their communities' values. Findings show that this constant negotiation strongly relates to women's conflicting roles as gatekeepers and agents-of-change. Navigating between these conflicting roles through nonuse, control, and limitations on the Internet constitutes a valuable currency in these women's cultural and religious markets, offering subtle ways through which they can build their agency.

This study thus shifts the spotlight from Internet use to Internet non (or limited) use, highlighting, perhaps counter-intuitively, the added value of the latter in religious contexts. The focus on women from strict and bounded religious communities could help us find new answers to complicated questions about the multifaceted composites of religion, modernity, technology, and gender.

\section{The study of new media among religious communities}

The individualism, autonomy, personal empowerment, and networking that characterize new media pose a challenge to the core values of religious communities: traditionalism, cultural preservation, collective identity, hierarchy, patriarchy, authority, self-discipline, and censorship (Campbell, 2004, 2007). Campbell (2010) developed a model for analyzing the complex relationship between religious societies and new media based on four dimensions: the history and tradition of the community, core beliefs and patterns, the negotiation process, and communal framing and discourse. Audience research studies the relationship between the consumer, and media technologies and content in mass communication (Press and Livingstone, 2006). Hoover and Lundby (1997) argued that audience research enables investigators to deal with important aspects of the daily relationships between religious people and media: the making of meaning (Hoover, 2006). Comparative audience studies ascribe importance to social, economic, political, and cultural differences, underscoring various conceptual limitations that result from ignoring these distinctions (Esser and Hanitzsch, 2012; Stausberg, 2011).

Feminist theories and methods created a critical point of view at the juncture between media and religion studies (Lövheim, 2013). Agency will be used as a key term in this article and will rely on Mahmood's (2005) insight that defines agency "not simply as a synonym for resistance to social norms, but as a modality of action that specific relations of subordination create and enable" (pp. 17-18). She expanded on feminist views of agency by showing its multiple forms and modalities and suggested changing the view that obedience-empowerment and surveillance-independence are dichotomies.

According to Campbell (2010) and Lövheim (2011), individuals' exercise of agency in religious communities can be understood as their ability, as active actors, to use and shape the media according to their values and needs. Religious women's uses of new media can change or even shift their religious identity in terms of authority, authenticity, and agency (Hess, 2013). The specific important connection to this research stems from the insight that Internet nonuse could enable control, empowerment, and agency among the nonusers who choose not to use it (Hakkarainen, 2012; Wyatt et al., 2005).

The present research looks into questions relating to gender, technology, and agency through the focal point of two communities: Old Order Amish and ultra-Orthodox 
Jews. The Amish are an ethno-cultural religious group affiliated with the Anabaptist Church, residing in the United States and Canada. They number close to 300,000, or less than $0.001 \%$ of the American population (Kraybill et al., 2013). Their religious and social lives are dictated by the Ordnung (literally, order), a set of rules that stresses humility, simplicity, and obedience (Hostetler, 1993; Kraybill, 2001). The Israeli ultraOrthodox are a Jewish religious group that constitutes $9.1 \%$ of Israel's adult population (Central Bureau of Statistics-Israel, 2015). Their religious and social life is bound by a rigid interpretation of Jewish religious law, a commitment to the study of Torah, and unquestioning faith in rabbinic authority (El-Or, 1994; Friedman, 1991). Henceforth, the term "devout orthodox communities" will be used to describe the two communities.

The few comparative studies of the two groups conducted to date (Neuberger, 2011; Neuberger and Tamam, 2014; Spinner, 1994) pointed to differences in levels of schooling and to attitudes toward state involvement in health and education. For this article, the relevant comparative dimensions are that they are both devout orthodox communities that live among secular, Western, modern populations and differ from them in values (Almond et al., 2003; Douglas, 1966). Amish are an agrarian working society (Kraybill, 2001), while ultra-Orthodox are a society of scholars (Friedman, 1991). Ultra-Orthodox make pragmatic uses of technology, while Amish reject innovations, do not use electricity, and travel by horse and buggy. The reality of their use of technologies is in fact much more complex in both communities, involving an intricate combination of acceptance, rejection, and adaptation (Caplan, 2007; Cooper, 2006; Hurst and McConnell, 2010; Kraybill et al., 2013).

The leaders and ideologies of both communities may reject the Internet, fearing it will damage the souls of their followers, but they have made some accommodations that permit cautious use under strict limitations (Barzilai-Nahon and Barzilai, 2005; Campbell, 2010, 2015; Cohen, 2012; Cohen et al., 2008; Deutsche, 2009; Kraybill et al., 2013). The similarity of the communities is reflected not just in their responses to the Internet, but by their divergence from other strict religious communities: while evangelists (Hendershot, 2004), Sephardic Haredi rabbis, and the ultra-Orthodox Jewish Habad sect (Campbell, 2010) use the Internet as a tool to spread their mission, the communities this research focuses on want to keep themselves outside of the world.

The literature on Amish women is sparse. ${ }^{2}$ It includes historic aspects (Schmidt et al., 2002), discussions about their status and discourse in different Amish societies (JohnsonWeiner, 2001; Schmidt and Reschly, 2000; Van Ness, 1995), and their home births (Jolly, 2007). None have dealt with the Internet. The literature on ultra-Orthodox women is rich (e.g. Davidman, 1991; El-Or, 1994; Feder, 2013). Studies about ultra-Orthodox women and the Internet showed that they expressed ambivalence toward the Internet (Lev-On and Neriya-Ben Shahar, 2012; Livio and Tenenboim-Weinblatt, 2007; Neriya-Ben Shahar and Lev-On, 2011; Tydor Baumel-Schwartz, 2009).

This study focuses on what we can learn by comparing the uses and perceptions of the Internet by these women from two devout orthodox communities and how they cope with the associated tensions. More specifically, the research questions are (RQ1) what are the exposure patterns regarding the use of the Internet among Amish and ultraOrthodox women; (RQ2) what are their perceptions regarding the use of the Internet; 
and (RQ3) how do the women negotiate the incongruence between the advantages of the Internet and their community's values?

\section{Methods: the sampled population}

From the wide spectrum of Amish and ultra-Orthodox societies, two mainstream groups were chosen as the appropriate populations for this research: Old Order Amish and Lithuanian and Hassidic ultra-Orthodox. The focus here is on "mainstream" sub-communities that are generally familiar with the Internet but limit their use of it. While the scope of this study did not allow comparisons between more stringent (Nebraska Amish/"Mea Shearim" ultra-Orthodox) or more liberal (New Order Amish/Modern Orthodox) sub-groups, such investigations would constitute important future follow-ups of this study.

The study included 82 participants: 40 women of the Old Order Amish community living in Lancaster, PA, and 42 ultra-Orthodox women from various places in Israel. ${ }^{3}$ The study relied on "snowball" (or networking) sampling, which is particularly well-suited to closed communities (Lee, 1993). In order to overcome the internal homogeneity of each community, the research assistants, women from the respective communities, were instructed to approach individuals with different demographic characteristics and to set a number of "snowballs" in motion. Nevertheless, to ensure that the diversity of their answers was due to cultural rather than demographic differences between the samples, the women's ages and number of children were compared. No significant differences were found between Amish and ultra-Orthodox participants in terms of age or number of children.

\section{Modes of analysis}

Women who agreed to participate in the study were explained its purpose and assured there were no correct or incorrect answers to the questions. They were paid US\$10 for their time. Assistants hired from the community participated in the recruitment of subjects and administered the questionnaires, usually in the homes of the subjects.

The questionnaire consisted of yes/no and open-ended qualitative questions. Although it included questions about various media—newspapers and magazines; radio; television; Internet; corded, mobile, and smart phones - this article focuses only on answers related to the Internet. The Amish were inexperienced in responding to written questionnaires, partly because they receive only 8 years of schooling, in comparison with the ultra-Orthodox women, who had an average of 14 years of formal education. For purposes of comparison, they were given similar questionnaires, with some adjustments in the Hebrew version. The questionnaires were completely anonymous ${ }^{4}$ and were formulated with sensitivity to language and values. The data were analyzed quantitatively and qualitatively. Because most of the answers to the quantitative questions were "yes/no," the quantitative analysis included descriptive statistics. The qualitative analysis used a grounded-theory approach (Strauss and Corbin, 1990).

Some of the difficulties and issues I encountered while working on this project stem from the challenges associated with research on cloistered communities (Kraybill, 2008; 
Lee, 1993; Rier et al., 2008; Steinmetz and Haj-Yahia, 2006). My entry into the Amish community came from a personal connection with a family from Lancaster, PA, which led to my residing on their farm for six separate periods, during which I mainly washed dishes, worked in the fields, and ran errands for them with my car. The many hours of working side by side with the women yielded numerous interviews and insights, and even willingness to help in the distribution of the questionnaires. As I have much closer personal ties to the ultra-Orthodox population, entering it was not as challenging.

\section{Results}

Only $20 \%$ (8) of the Amish women had ever used the Internet, compared to $50 \%$ (21) of the ultra-Orthodox women. While both communities reported using the Internet for information-searching and shopping, the ultra-Orthodox use it mostly for work. These findings indicate that both communities reported a low but significant level of use; in contrast to eating pork among the ultra-Orthodox or car ownership among the Amish, the Internet is not completely prohibited, only restricted.

The key to understand the women's agency, which will be discussed below, is the combination of low usage levels and the main goal of use-fulfilling a basic value of their community: supplying the various needs of their families. The women manage their conduct by acting as agents-of-change when they use the Internet, and simultaneously as gatekeepers, by keeping their usage rates low, limited, and in keeping with the communities' restrictions.

The communities' overall media consumption shows that whereas newspapers and magazines are read by most of the women on a daily basis, television and radio exposure patterns are limited and are mostly out-of-home. Marvin (1988) noted that technologies like the telephone and electric light were considered threatening in the 19th century by some populations in the United States. Although the Internet is not unique in this sense, its ability to undermine the boundary between the holy home/community and "the world" (Zimmerman-Umble, 1992) could be conceived as being more dangerous than the old technologies. More than the problem of content, the fact that new technologies enable Internet connection without visible signs has limited the communities' ability to control their members' exposure to the world.

The complex relationship these women have with the Internet is reflected in their perceptions regarding the use of the Internet and how they negotiate the discrepancy between their needs and its advantages, on one hand, and their community's values and their leaders' positions, on the other. Their answers to the question "What do you think about the internet?" identified two main tensions as central to these reactions: ideology versus practice and social surveillance versus self-control.

\section{When ideology meets practice}

The Internet is a critical crossroad between two powers: from the ideological perspective, devout orthodox women are supposed to internalize - and then externalize - the prohibitions and their elders' warnings about the Internet. From the practical perspective, they know this is an important and helpful tool with many advantages. Their answers to 
my questions reflected their "language and symbols that provide a clear framework for how new technology should be viewed or integrated into the community" (Campbell, 2010: 134).

To the question "What do you think of the internet?," both communities expressed similar ideological warnings: "It is scary [...] I think it may be Satan's tool to draw our focus away from our trust in God" (Amish); "The internet is the most terrible thing ever. It's poison, a Satan, an angel of death" (ultra-Orthodox).

They chose very similar words to describe the Internet, which I categorize into the following groups: (1) destruction and ravage-danger, dangerous, catastrophe, spoils the spiritual world, a weapon, harmful; (2) degrading — garbage and filth, bad, shocking, filthy, horrible; (3) temptation - seductive, slippery slope; (4) access - uncensored information, worldly; (5) religious exclusion-impure, evil things forbidden by the church; (6) spiritual effects - destroys souls, influences thoughts; and (7) a waste of time - takes time away from family time.

Although the ideological discourse is similar, one of the main differences between the two communities is reflected in the pragmatic ultra-Orthodox view of technology as seen in their higher use pattern, compared to the predominant rejection behavior among the Amish (Caplan, 2007; Kraybill et al., 2013; Zimmerman-Umble, 1992).

\section{Social surveillance versus self-control}

The Amish and ultra-Orthodox, like other devout religious communities, have strict mechanisms of social surveillance to enforce their norms. Thus, many women from both societies noted the determined attitude of their communities' leaders against the Internet. But the reality is much more complicated - the authorities do not completely prohibit the Internet, and social surveillance takes into account circumstance and the limits imposed on its use.

The women were asked, "Do you think that browsing the Internet is in keeping with Amish/ultra-Orthodox values?" Of the total, 97\% (39) of the Amish and 95\% (40) of the ultra-Orthodox answered "No." Clearly, the Internet is not considered compatible with the communities' values. The open answers to this question emphasized the role of social norms: "By doing so we displease the majority of the Amish who do not approve of the internet"; "Internet use is not appropriate to ultra-Orthodox society"; "Our leaders have decided it is something we do not want among our people"; "When the rabbis prohibit we believe and don't ask questions."

While many women completely accepted these values and never used the Internet, others described three control mechanisms they adhered to: (1) technical control afforded by content censure ${ }^{5}$ “A blocked internet is a Kosher internet" (ultra-Orthodox); (2) self-control- "It's only as good as the people who use it" (Amish); and (3) out-of-thehome use - only in public libraries or the workplace.

The mechanism of self-control is even stronger in their answers to this hypothetical question: "If the Amish/ultra-Orthodox society were allowed to use one of these devices - television, radio, or the Internet-which would you choose?" Of the Amish, $40 \%$ (16) and of the ultra-Orthodox, $43 \%$ (18) answered they would not choose any of them. The remaining women chose one of them. I would argue that the fact a large 
minority answered that they consider these technologies prohibited even though their communities allow them, is significant. The women do not limit themselves only on the basis of rules set by their communities and leaders; in fact, their independent thinking and values lead them to be even stricter than those rules. For example, "None of them tempt me at all!" (Amish) and "I don't need a rabbi to prohibit or permit, I can understand the damages by myself" (ultra-Orthodox). These answers were the first clues to the agency these women enjoyed in their community.

\section{The women's agency: gatekeepers and agents-of-change}

How do the women in the two communities live with the gap between their values and rate of Internet use? We can address this question through the terms "gatekeeper" and "agent-of-change." Campbell (2010) wrote about the important role of gatekeepers in religious-hierarchical societies. Barzilai-Nahon (2008) defined gatekeeping as "the process of controlling information as it moves through a gate" (p. 1496). Douglas (1966) argued that the gatekeeper keeps out the "out of us" and lets in the "part of us."

The main gatekeepers in religious communities are probably the women. While religious communities perceive men as providing leadership and direction, in practice, women's roles as educators and homemakers position them as central in defending their communities from threatening changes (El-Or, 1994; Johnson-Weiner, 2001; NeriyaBen Shahar, 2008). The very same roles, almost paradoxically, allow women to simultaneously act as agents-of-change, as they connect with the surrounding secular world to provide for their families' needs (especially through work and shopping). The significant changes among Amish and ultra-Orthodox women as they assume jobs and run businesses have important ramifications on both the economic and social realms (Kraybill et al., 2013; Neriya-Ben Shahar, 2008).

As agents-of-change, women take into account not only ideology but practical considerations as well, meeting the existential needs of those in their charge while attempting to be independent. In analyzing the women's answers, I found that most of them were mixed, integrating both metaphors: "The internet is a worldly thing. It is misleading and filthy. Then again, it may have [...] good programs" (Amish); "The internet is Satan's greatest invention [...] a great device and useful [...] and a destroyer" (ultra-Orthodox).

The women's dual answers could be understood simply as ambivalence or as "false consciousness," which, according to Reinharz (1992), pervades feminist ethnography of nonfeminist groups. However, a careful feminist reading of the answers could show a "strong multiplicity" (Hartman, 2015). I suggest that those multiplicities create a broad spectrum that encompasses both categories.

Deciphering how women negotiate the two tensions depicted above can help us understand relationships between women from devout orthodox communities and the Internet. Gatekeeper and agent-of-change are not binary categories, but rather spheres of conduction and motion. The women manage the paradoxes and tensions through cautious navigation between the gatekeeper sphere, which includes ideology and social surveillance, and the agent-of-change sphere, which includes careful practice and self-control. 
For this discussion, I will draw a triangle that depicts women's agency in devout communities as based on three pillars: Internet nonuse (as the base of the triangle), complex conduction, and rigorous adherence to religious dictates. While each of these components may appear, at first glance, antithetical to the secular, liberal use of "agency," I will claim, building on Mahmood's (2005) work, that in fact they work together to empower ultra-religious women.

Side I: the base of the triangle - Internet nonuse as agency. Hargittai (2004) argued that the question "how does one not use the Internet" is not less important than "how does one use the Internet." This focus is usually part of extensive social and scholarly dealing with digital divides (Livingston and Helsper, 2007; Selwyn, 2004). The common argument is that Internet use enables empowerment and partnership, which is especially important for excluded communities (Mehra et al., 2004); a different perspective, however, argues that Internet nonuse could enable control, empowerment, and agency among the nonusers who choose not to use it (Hakkarainen, 2012; Selwyn, 2003; Wyatt et al., 2005). For example, Portwood-Stacer (2012) showed that the ability to choose to not use Facebook is meaningful in terms of cultural and social capital.

In comparison with these arguments that focus on nonuse of the Internet as empowerment at the individual level and following a definition of agency suggested by Saba Mahmood (2005) — “a modality of action that specific relations of subordination create and enable" (pp. 17-18) - this research focuses on the community level. Taking into account that the ideologies and values of both the Amish and ultra-Orthodox strongly oppose the Internet and its implications, my claim is that Internet nonuse constitutes an important part of communal identity and sense of belonging. As such, it has potential for creating agency, empowerment, and partnership for community members.

Side 2: religious women's complex conduction as agency. Avishai (2008) argued that religious women are authentic subjects who choose their religious conduct, experiences, and complex identity. She followed Mahmood (2005) and expanded on feminist views of agency by showing its multiple forms and modalities. Although critical responses among feminist writers are rich and have raised important theoretical and epistemological questions (Bangstad, 2011; Gourgouris, 2008), I argue that we need to listen to the participants' voices. If these women wrote that their experiences included feelings of control, choice, and power, we cannot simply dismiss these notions as "false continence."

Side 3: rigorous adherence to religious dictates as agency. Bourdieu (1986) used the terms market, capital, and practices to describe the complicated relationships between social actors in all societies. Friedman (1993) based his market model on religious radicalism. He argued that in devoted communities, rigorous adherence to religious dictates is highly admired, and compromising is a symbol of lower religiosity. Therefore, members of such communities can use their stringency as capital that demonstrates their piety. The strong independent social actors of the religious market use their stringency as shares and capital that demonstrate their piety.

Because this triangle clearly converges around multiple forms and modalities of agency, I argue that Amish and ultra-Orthodox women have a wide range of opportunities 
and choices, one of which is Internet use. Amish women have long, quiet hours at home; ultra-Orthodox women's workplaces have Internet connections, sometimes free. Most of them could use the Internet more than they actually do. We can see that the women's ability to choose, to move between being gatekeeper and agent-of-change, is part of their agency. The women expressed their independence by making decisions; by choosing whether, how, when, and why to use the Internet; and how it should be controlled.

If we look at these women as active actors in the Amish and ultra-Orthodox markets, they use their power in the community to raise their social capital, although their currency is different from that of Western and modern society (Tan, 1998). If the coins of modern societies are what we have and use, their coins are what they do not have and do not use. Nonuse constitutes an important part of one of the most valorized aspects in those communities' value systems: isolation from mainstream society. The interviewees have internalized the various symbolic aspects associated with isolation, and their agency is reflected in what they consider their clever conduct.

For example, we can listen to one woman who understands her market and knows how to increase her value in it:

The internet without blocks and control is dangerous. Our sages said: "Until the day you die, do not believe in yourself." I give up the convenience, the availability of the information that I need, the cheaper stuff that I could get. The internet is a work tool and belongs only in the workplace. I created for myself a homepage that blocks pop-ups, and I can get access only to legitimate websites that I need for my work. I made it a limit for myself. (Ultra-Orthodox)

This woman uses her agency to navigate between the Internet's perceived advantages and disadvantages; she empowers herself through self-control. This, I contend, is not just a collection of ambivalent or multiple attitudes toward a great and dangerous new technology, but a powerful component of devoted-women's agency.

To illustrate this point, I wish to highlight a common theme that emerged from my participant observations in both communities. Mahmood's agency as modality of action could be seen on a daily basis when observing the women acting as a wall holding back their children, especially the youth, who try to "push the limits," in the words of an Amish woman. For example, one ultra-Orthodox girl asked to lower the filter levels of the "kosher internet"; a young Amish boy negotiated with his mother, who demanded he stop watching television in Wal-Mart. The children's repeated argument was "our friends do it," to which the mothers repeatedly replied, "They only call themselves Amish (or ultra-Orthodox)" or "They are modern, they are not 'ours'." By doing so, these gatekeeping women create and maintain the community's borders.

However, the same women may act as agents-of-change, especially if they have a pressing need of their own or are afraid that one of their children may eventually leave the community because of its strict rules. In these situations, they may carefully adapt elements from the modern world for their families' use, like a weekly Internet session in the public library. They understand that gatekeeping serves not only to close but also to open the gates, if only slightly.

For the most part, though, these women insist on setting limits, therefore maintaining the values of their communities and nurturing subordination to these strictures in their 
children. Their conduct as agents-of-change is thus limited and careful. This is critical to both forging the family's positive image in the community market and increasing the community's value as whole. By creating, accepting, and maintaining various limitations and subordination, the women are building a whole greater than the sum of its parts: a pious and devoted community that appreciates and accepts these limitations and barriers.

\section{Conclusion}

This study is situated at a juncture between media, religious, and gender studies. Its main contribution is that non (or limited) use of media creates valuable cultural and religious capital for religious women who try to bridge the gap between their roles as gatekeepers and agents-of-change. The comparison between Amish and ultra-Orthodox women described in this article reveals complicated and sophisticated perceptions of Internet use. It both sharpens the differences between them and underscores the similarities in their discourse about this meta-medium.

The similarities were ideological: the women from both communities perceived the Internet as incompatible with their community's values, and their discourses (Campbell, 2010) included very similar language regarding danger and threat. Another similarity is their obedience to their leaders. Many women from both societies noted the determined opposition of their leaders to the Internet, but quoted them without criticism. This marks one of the most important boundaries between devout and nondevout communities: obedience and unquestioning faith in religious authority (Friedman, 1991; Kraybill et al., 2013).

The difference lies in their Internet use patterns. It would be easy to explain by noting that ultra-Orthodox women have more schooling and work outside the home to a greater extent than the Amish, or even simpler - that the ultra-Orthodox community has electricity. However, if the communities' values are similar, how can their Internet usage patterns be so different?

The answer may lie in the two communities being separated from the surrounding society, but not isolated from it. Both the Amish in America and the ultra-Orthodox in Israel are surrounded by Western, secular, and modern society, inevitably creating an ideological discourse of threat, of which the Internet is one element. The threat mechanism, on one hand, and the agency mechanism, on the other, are integral parts of devout orthodox communities, regardless of education, occupation patterns, urban/rural residences, and responses to technology. Therefore, in both societies, women exercise their agency to preserve their community's values and supply its needs. They negotiate the tricky path between opting to meet the community's needs and limiting themselves in order to stay within the boundaries of the permissible (by the authorities) and the acceptable (by their peers).

Despite the above, the careful comparative reading shows that beyond the sociodemographic explanation, the ultra-Orthodox women's answers were more complicated and longer than the Amish's. I would suggest that such answers indicate a more complex relationship with the Internet. The reality of ultra-Orthodox women's lives and their community's complicated relationship with modern society forces them to use the Internet while simultaneously advocating the opposite. The Amish women's simple 
answers indicated their more "plain and simple" lives, which enable them to live more in line with the restrictions of their society.

It is not new that religious communities manage complicated negotiations with the media based on their traditions and values (Campbell, 2010) and that they are active actors with agency (Lövheim, 2013). Nor is it new that negotiation is an important part of the complexity of religious women's empowerment and agency (Avishai, 2008; Mahmood, 2005) or that Internet nonuse could enable agency among nonusers (Hakkarainen, 2012). The main contribution of this article is the understanding that the perception of the Internet by women from devout communities combines all these elements almost at once. The innovative insight is that the ability to negotiate the tension between the roles of gatekeeper and agent-of-change through nonuse, control, and limitations vis-a-vis the Internet constitutes a valuable currency in the cultural and religious markets of women from devout communities. One must look carefully at the triangle of Internet nonuse, rigorous adherence to religious dictates, and complex conduction among religious women for the subtle ways women could create and build their agency. In our case, this scrutiny, which surfaces only as a result of respectful comparison between those communities, leads to re-framing nonuse of the Internet by devout orthodox women as a sign of empowerment among strong independent actors who hold many shares in the religious market, rather than as a marker of weakness and the women as unlucky victims of a digital divide.

As an addition to the rich literature on digital religion as a source of new religious experiences and self-empowerment (Campbell, 2013), this study draws attention to the other part of these communities: the $80 \%$ of the Amish and $50 \%$ of the ultra-Orthodox participants who never use the Internet. These women see themselves as true gatekeepers - well aware of what they are missing, they choose not to use it, period. "The more simply you live without, the easier to stay godly within," says 26-year-old Rachel, an Amish, as we shell peas together. "It can be a slippery slope." Nonuse of the Internet construed as a means to become closer to God is one way these women exercise their agency and empowerment. They demonstrate that they are gatekeepers - an important part of their communities - and simultaneously agents-of-change, capable of managing their relationships with the modern world.

The issues addressed here need to be investigated further with larger samples that include Amish and ultra-Orthodox men and compare men and women from diverse devout orthodox and liberal communities. Such studies could provide information about how women and men in these communities use their agency to negotiate the gaps between their rigid ideologies and daily practices.

\section{Acknowledgements}

I would like to thank the editors and anonymous reviewers for their constructive comments and suggestions, and Helene Landau for her skillful editing. I am also grateful to Sapir Academic College and the Israeli Second Authority for Television and Radio for their support of this research.

\section{Funding}

The author(s) disclosed receipt of the following financial support for the research, authorship, and/ or publication of this article: Sapir Academic College and the Israeli Second Authority for Television and Radio supported this research. 


\section{Notes}

1. This research does not include the Habad and Breslav ultra-orthodox Jewish sects because their use of the Internet is different than that of the others.

2. Bender (1989) and Stoltzfus (1994) are very interesting reads, but they are not based on academic studies.

3. I relied on the self-definition of the respondents (Friedman et al., 2011; Pew Research Center, 2013).

4. Like Cooper (2006).

5. The ultra-Orthodox have technologies for applying various levels of Internet censure and blocking (Campbell, 2010).

\section{References}

Almond GA, Appelby RS and Sivan E (2003) Strong Religion: The Rise of Fundamentalisms Around the World. Chicago, IL: The University of Chicago Press.

Avishai O (2008) "Doing religion" in a secular world: women in conservative religions and the question of agency. Gender \& Society 22: 409-433.

Bangstad S (2011) Saba Mahmood and the anthropological feminism after virtue. Theory, Culture \& Society 28(3): 28-54.

Barzilai-Nahon K (2008) Toward a theory of network gatekeeping: a framework for exploring information control. Journal of the American Society for Information Science and Technology 59(9): 1493-1512.

Barzilai-Nahon K and Barzilai G (2005) Cultured technology: the internet and religious fundamentalism. The Information Society 21(1): 25-40.

Bender S (1989) Plain and Simple: A Woman's Journey to the Amish. New York: HarperCollins Publications.

Bourdieu P (1986) The forms of capital. In: Richardson JE (ed.) Handbook of Theory of Research for the Sociology of Religion. New York: Greenwood, pp. 241-258.

Campbell H (2004) Challenges created by online religious networks. Journal of Media and Religion 3(2): 81-99.

Campbell H (2007) Who's got the power? Religious authority and the internet. Journal of Computer-Mediated Communication 12: 1043-1062.

Campbell H (2010) When Religion Meets New Media. London: Routledge.

Campbell H (ed.) (2013) Digital Religion: Understanding Religious Practice in New Media Worlds. London: Routledge.

Campbell H (ed.) (2015) Digital Judaism: Jewish Negotiations with Digital Media and Culture. New York: Routledge.

Caplan K (2007) The Internal Popular Discourse in Israeli Haredi Society. Jerusalem: Zalman Shazar (in Hebrew).

Central Bureau of Statistics-Israel (2015) Statistical Abstract of Israel, Table 7.6. Jerusalem. http://www.cbs.gov.il/reader/shnaton/text_search_eng_new.html?CYear=2015\&Vol=66\&in put $=$ orthodox

Cohen AA, Lemish D and Schejter A (2008) The Wonder Phone in the Land of Miracles. New York: Hampton Press.

Cohen Y (2012) God, Jews and the Media: Religion and Israel's Media. London: Routledge.

Cooper TW (2006) Of script and scriptures: why plain people perpetuate a media fast. The Journal of American Culture 29(2): 139-153.

Davidman L (1991) Tradition in a Rootless World: Women Turn to Orthodox Judaism. Berkeley, CA: University of California Press. 
Deutsche N (2009) The forbidden fork, the cell phone holocaust, and other Haredi encounters with technology. Contemporary Jewry 29: 3-19.

Douglas M (1966) Purity and Danger: An Analysis of Concepts of Pollution and Taboo. London: Routledge \& Kegan Paul.

El-Or T (1994) Educated and Ignorant: Ultraorthodox Jewish Women and their World. Boulder, CO: Lynne Rienner Publishers.

Esser F and Hanitzsch T (2012) Organizing and managing comparative research projects across nations. In: Volkmer I (ed.) The Handbook of Global Media Research. Hoboken, NJ: WileyBlackwell, pp. 521-532.

Feder A (2013) Nonliberal Jewish women's audiocassette lectures in Brooklyn: a crisis of faith and the morality of media. American Anthropologist 115(1): 72-84.

Friedman I, Shaul-Mena N, Fogel N, et al. (2011) Measurement and Estimates of the Population of Ultra-Orthodox Jews. Jerusalem: Central Bureau of Statistics (in Hebrew).

Friedman M (1991) Haredi Society: Sources, Trends and Processes. Jerusalem: Jerusalem Institute for Israel Studies (in Hebrew).

Friedman M (1993) The market model and religious radicalism. In: Silberstein LJ (ed.) Jewish Fundamentalism in Comparative Perspective: Religion, Ideology and the Crisis of Modernity. New York: New York University Press, pp. 192-215.

Gourgouris S (2008) Antisecularist failures: a counter-response to Saba Mahmood. Public Culture 20(3): 453-459.

Hakkarainen P (2012) "No good for shoveling snow and carrying firewood": social representations of computers and the internet by elderly Finnish non-users. New Media \& Society 14(7) $1198-1215$.

Hargittai E (2004) Internet access and use in context. New Media \& Society 6(1): 137-143.

Hartman T (2015) "Strong multiplicity": an interpretive lens in the analysis of qualitative interview narratives. Qualitative Research 15(1): 22-38.

Hendershot H (2004) Shaking the World for Jesus: Media and Conservative Evangelical Culture. Chicago, IL: The University of Chicago Press.

Hess ME (2013) Digital storytelling: empowering feminist and womanist faith formation with young women. In: Lövheim M (ed.) Media, Religion and Gender: Key Issues and New Challenges. London: Routledge, pp. 169-182.

Hoover SM (2006) Religion in the Media Age. New York: Routledge.

Hoover SM and Lundby K (eds) (1997) Rethinking Media, Religion and Culture. Thousand Oaks, CA: SAGE.

Hostetler JA (1993) Amish Society. Baltimore, MD: Johns Hopkins University Press.

Hurst CE and McConnell DL (2010) An Amish Paradox: Diversity and Change in the World's Largest Amish Community. Baltimore, MD: Johns Hopkins University Press.

Johnson-Weiner K (2001) The role of women in Old Order Amish, Beachy Amish and Fellowship Churches. Mennonite Quarterly Review LXXV(2): 231-256.

Jolly N (2007) Public culture, private birth: social pattern of Amish domestic space. Unpublished Doctoral Thesis, Pennsylvania State University, Philadelphia, PA.

Kraybill DB (2001) The Riddle of Amish Culture. Baltimore, MD; London: Johns Hopkins University Press.

Kraybill DB (2008) Amish informants: mediating humility and publicity. In: Zimmerman-Umble $\mathrm{D}$ and Weaver-Zercher D (eds) The Amish and the Media. Baltimore, MD: Johns Hopkins University Press, pp. 161-180.

Kraybill DB, Johnson-Weiner KM and Nolt SM (2013) The Amish. Baltimore, MD: Johns Hopkins University Press.

Lee RM (1993) Doing Research in Sensitive Topics. London: SAGE. 
Lev-On A and Neriya-Ben Shahar R (2012) To browse, or not to browse? Third person effect among ultra-Orthodox Jewish women, in regards to the perceived danger of the internet. In: Cheong PH, Martin JN and Macfadyen L (eds) New Media and Intercultural Communication. New York: Peter Lang, pp. 223-236.

Livingstone S and Helsper E (2007) Gradations in digital inclusion: children, young people and the digital divide. New Media \& Society 9(4): 671-696.

Livio O and Tenenboim-Weinblatt K (2007) Discursive legitimation of a controversial technology: ultra-Orthodox Jewish women in Israel and the internet. The Communication Review 10(1): 29-56.

Lövheim M (2011) Mediatisation of religion: a critical appraisal. Culture and Religion 12(2): $153-166$.

Lövheim M (ed.) (2013) Media, Religion and Gender: Key Issues and New Challenges. London: Routledge.

Mahmood S (2005) The Politics of Piety: The Islamic Revival and the Feminist Subject. Princeton, NJ: Princeton University Press.

Marvin C (1988) When Old Technologies Were New. Oxford: Oxford University Press.

Mehra B, Merkel C and Bishop AP (2004) The internet for empowerment of minority and marginalized users. New Media \& Society 6(6): 781-802.

Neriya-Ben Shahar R (2008) Haredi (Ultra-Orthodox) women and mass media in Israel: exposure patterns \& reading strategies. Unpublished Doctoral Thesis, The Hebrew University of Jerusalem, Jerusalem (in Hebrew).

Neriya-Ben Shahar R and Lev-On A (2011) Gender, religion and new media: attitudes and behaviours related to the internet among ultra-Orthodox women employed in computerized environments. International Journal of Communication 5: 875-895.

Neuberger B (2011) The Amish, the rule of law and freedom of religion-The culture of compromise in American democracy. Democratic Culture 12: 115-140.

Neuberger B and Tamam KM (2014) The image of the Amish in the New York Times versus the image of the Haredim in Haaretz (1980-2010). Conflict and Communication Online 13(1): $1-17$.

Pew Research Center (2013) A Portrait of Jewish Americans. Available at: http://www.pewforum. org/2013/10/01/jewish-american-beliefs-attitudes-culture-survey/

Portwood-Stacer L (2012) Media refusal and conspicuous non-consumption: the performative and political dimensions of Facebook abstention. New Media \& Society 15(7): 1041-1057.

Press AL and Livingstone S (2006) Taking audience research into the age of new media: old problem and new challenges. In: White M and Schwoch J (eds) The Question of Method in Cultural Studies. London: Blackwell Publishing, pp. 175-200.

Reinharz S (1992) Feminist Methods in Social Research. New York; Oxford: Oxford University Press.

Rier DA, Schwartzbaum A and Heller C (2008) Methodological issues in studying an insular, traditional population: a women's health survey among Israeli Haredi (ultra-Orthodox) Jews. Women \& Health 48(4): 363-381.

Schmidt KD and Reschly SD (2000) A women's history for Anabaptist tradition: a framework of possibilities, possibly changing the framework. Journal of Mennonites Study 18: 29-46.

Schmidt KD, Zimmerman-Umble D and Reschly SD (2002) Strangers at Home: Amish and Mennonites Women in History. Baltimore, MD: Johns Hopkins University Press.

Selwyn N (2003) Apart from technology: understanding people's non-use of information and communication technologies in everyday life. Technology in Society 25(1): 99-116.

Selwyn N (2004) Reconsidering political and popular understanding of the digital divide. New Media \& Society 6(3): 341-362. 
Spinner J (1994) The Boundaries of Citizenship: Race, Ethnicity and Nationality in the Liberal State. Baltimore and London: Johns Hopkins University Press.

Stausberg M (2011) Comparison. In: Stausberg M and Engler S (eds) The Routledge Handbook of Research Methods in the Study of Religion. London: Routledge, pp. 21-39.

Steinmetz S and Haj-Yahiye M (2006) Definitions of and beliefs about wife abuse among ultraOrthodox Jewish men from Israel. Journal of Interpersonal Violence 21(4): 525-554.

Stoltzfus L (1994) Amish Women: Lives and Stories. Intercourse, PA: Good Books.

Strauss A and Corbin JM (1990) Basics of Qualitative Research. Thousand Oaks, CA: SAGE.

Tan TK (1998) Silence, sacrifice and shoo-fly pies: an inquiry into the social capital organizational strategies of the Amish community in Lancaster country, Pennsylvania. Unpublished Doctoral Thesis, Harvard University, Cambridge, MA.

Tydor Baumel-Schwartz J (2009) Frum surfing: orthodox Jewish women's internet forums as a historical and cultural phenomenon. Journal of Jewish Identities 2(1): 1-30.

Van Ness S (1995) Ohio Amish women in the vanguard of a language change: Pennsylvania German in Ohio. American Speech 70(1): 69-80.

Wyatt S, Henwood F, Hart A, et al. (2005) Digital divide, health information and everyday life. New Media \& Society 7(2): 199-218.

Zimmerman-Umble D (1992) The Amish and the telephone: resistance and reconstruction. In: Silverstone R and Hirsh E (eds) Consuming Technologies: Media and Information in Domestic Spaces. London: Routledge, pp. 183-194.

\section{Author biography}

Rivka Neriya-Ben Shahar is a lecturer at Sapir Academic College in Sderot, Israel. She was a Fulbright post-doctoral fellow in 2011-2012 and a Scholar in Residence at the Hadassah-Brandeis Institute at Brandeis University. Her studies focus on the mass media from the perspectives of religion and gender. 